\title{
Persistence of wild Streptococcus thermophilus strains on wooden vat and during the manufacture of a traditional Caciocavallo type cheese
}

\author{
L. Settanni *, A. Di Grigoli, G. Tornambé, V. Bellina, N. Francesca, G. Moschetti, A. Bonanno \\ DEMETRA Department, University of Palermo, Viale delle Scienze 4, 90128 Palermo, Italy
}

\section{A R T I C L E I N F O}

\section{Article history:}

Received 28 September 2011

Received in revised form 19 December 2011

Accepted 25 January 2012

Available online 1 February 2012

\section{Keywords:}

Lactic acid bacteria biodiversity

"Pasta filata" cheese

Streptococcus thermophilus

Wooden dairy plant equipment

\begin{abstract}
A B S T R A C T
The present work was undertaken to evaluate the influence of the wooden dairy plant equipment on the microbiological characteristics of curd to be transformed into Caciocavallo Palermitano cheese. Traditional raw milk productions were performed concomitantly with standard cheese making trials carried out in stainless steel vat inoculated with a commercial starter. Milk from two different farms (A and B) was separately processed. The wooden vat was found to be a reservoir of lactic acid bacteria (LAB), while unwanted (spoilage and/or pathogenic) microorganisms were not hosted or were present at very low levels. All microbial groups were numerically different in bulk milks, showing higher levels for the farm B. LAB, especially thermophilic cocci, dominated the whole cheese making process of all productions. Undesired microorganisms decreased in number or disappeared during transformation, particularly after curd stretching. LAB were isolated from the wooden vat surface and from all dairy samples, subjected to phenotypic and genetic characterization and identification. Streptococcus thermophilus was the species found at the highest concentration in all samples analyzed and it also dominated the microbial community of the wooden vat. Fourteen other LAB species belonging to six genera (Enterococcus, Lactobacillus, Lactococcus, Leuconostoc, Streptococcus and Weissella) were also detected. All $S$. thermophilus isolates were genetically differentiated and a consortium of four strains persisted during the whole traditional production process. As confirmed by $\mathrm{pH}$ and the total acidity after the acidification step, indigenous $S$. thermophilus strains acted as a mixed starter culture.
\end{abstract}

(c) 2012 Elsevier B.V. All rights reserved.

\section{Introduction}

In the last few years, the increasing trend of consumers towards "natural" food products has resulted in a re-discovery and appreciation of traditional cheeses with a strong typicality. The autochthonous microflora (starter and non starter) is claimed to play a major role in the determination of the specific cheese characteristics (Piraino et al., 2005). For this reason several cheeses, particularly those enjoying a protected denomination of origin (PDO) status, including "pasta filata" cheeses, have been investigated extensively for the diversity of their LAB microflora and the main species have been technologically characterized at the strain level (Morea et al., 2007; Piraino et al., 2008).

Stretched ("pasta filata") cheeses owe their designation to the characteristic technology of production consisting of two distinct steps, the first leading to a plastic curd and the second to the scalding of the acidified curd to be molded into the final shape. Following these steps, the cheese is left to ripen (Salvadori del Prato, 1998). Caciocavallo is one of the most well known "pasta filata" cheeses; it is mainly manufactured in southern regions of Italy, but also in Balkanian Countries, where it is known as Kachkaval (Petrova, 1975).

\footnotetext{
* Corresponding author. Tel.: + 39091 23896043; fax: + 390916515531.

E-mail address: luca.settanni@unipa.it (L. Settanni).
}

Caciocavallo Palermitano cheese is manufactured within the Palermo province (Sicily, Italy) exclusively from raw cow's milk. This cheese represents one of the niche Sicilian food products that best links its history to the production area. In fact, this cheese is manufactured traditionally in small size farms of inland Sicily where cows of indigenous breeds, especially Cinisara, are fed mainly on poor natural pasture. The production protocols of caciocavallo differ from the common technology applied for "pasta filata" cheeses, since the majority of caciocavallo varieties are processed without addition of starter culture or natural whey starter culture (NWSC). Caciocavallo Palermitano cheese making is carried out employing traditional wooden dairy equipment which is thought to contribute strongly to the typicality of the final product which is parallelepiped-shaped with a weight of approximately $10 \mathrm{~kg}$ (Bonanno et al., 2004; Tornambè et al., 2009).

Several raw milk cheese types are produced without starter addition; in this case, the activity of indigenous lactic acid bacteria (LAB), present as contaminants of milk (Franciosi et al., 2009), is important to ensure the consistent lactic acid production within the first hours after curdling, in order to inhibit unwanted (spoilage and/or pathogenic) bacteria (Holzapfel et al., 1995).

The wooden vats used to produce Ragusano PDO, another Sicilian caciocavallo cheese, represent safe systems, since they have been found to host high levels of LAB, mainly Streptococcus thermophilus (Licitra et al., 2007), while pathogens such as Salmonella species, 
Listeria monocytogenes and Escherichia coli 0157:H7 are generally absent (Lortal et al., 2009). S. thermophilus is a common species of NWSC (Settanni and Moschetti, 2010). Thus, it is employed to produce cheeses that undergo cooking and/or stretching of curd. The work performed on Ragusano cheese showed the dominance of this species over other microbial groups, but the authors (Lortal et al., 2009) did not investigate $S$. thermophilus biofilms at the strain level.

Traditional productions are generally characterized by a high microbial and genetic diversity of the culture isolates (Topisirovic et al., 2006; Psoni et al., 2007; Nieto-Arribas et al., 2009; Alegría et al., 2009). Hence, the dominance of technologically relevant strains is crucial to minimize microbial variability during the ripening process.

This study is part of a project aimed to evaluate the influence of traditional equipment on the quality of Caciocavallo Palermitano cheese. The present work examined the effects of the wooden vat on the microbiological characteristics of curd during production, before the ripening process took place. In particular, the objectives pursued in this paper were to study the composition of LAB during cheese manufacture and to evaluate the persistence and/or dominance of LAB from wooden tools.

\section{Materials and methods}

\subsection{Cheese production and sample collection}

Raw cow's milk to be processed into cheese was collected from two farms (A and B) located within the Palermo province (Sicily, Italy) and delivered to a local dairy factory (Godrano, Palermo province). The bulk milks from the two farms were processed separately. Each bulk milk was delivered once a day; it comprised the milk from the evening milking, kept refrigerated under slow stirring, plus the milk from the morning milking. The bulk milk of each traditional Caciocavallo Palermitano cheese production (Fig. 1) was transferred into a wooden vat, called "tina", where it generally remains few minutes before rennet addition. The wooden vat was never used to produce cheese with the addition of starters. The two traditional productions (TA and TB), each performed in triplicate in three consecutive weeks, were closely followed to collect milk, curd and whey samples (Table 1) for analysis. The internal surfaces of the wooden vat (side surface, base surface and interface base/lateral surface), the same for all traditional productions, were also sampled; sterile cotton swabs were streaked onto $100 \mathrm{~cm}^{2}$ areas, just before cheese production took place. The presence of LAB on the internal surfaces of the stainless steel vat was also checked.

Two standard Caciocavallo Palermitano cheese productions (SA and SB) were carried out in a stainless steel vat inoculated with a commercial freeze-dried starter preparation (LYOBAC-D T, Alce International s.r.l., Quistello, Italy). As above, they were performed in triplicate in the same days of traditional cheese productions (Table 1 ).

\subsection{Microbiological analysis}

Decimal dilutions of milk (10 mL), whey $(10 \mathrm{~mL})$ and surface (cotton swabs streaked onto $100 \mathrm{~cm}^{2}$ were suspended in $10 \mathrm{~mL}$ Ringer's solution) samples were prepared in Ringer's solution. The first dilution of curd samples ( $10 \mathrm{~g})$ was performed in sodium citrate $(2 \% \mathrm{w} / \mathrm{v})$ solution by homogenization using a classic blender, while further serial dilutions were continued in Ringer's solution. Microbial suspensions were plated and incubated as follows: total mesophilic count (TMC) on plate count agar (PCA) with $1 \mathrm{~g} \mathrm{~L}^{-1}$ added skimmed milk (SkM), incubated aerobically at $30^{\circ} \mathrm{C}$ for $72 \mathrm{~h}$; total psychrotrophic counts

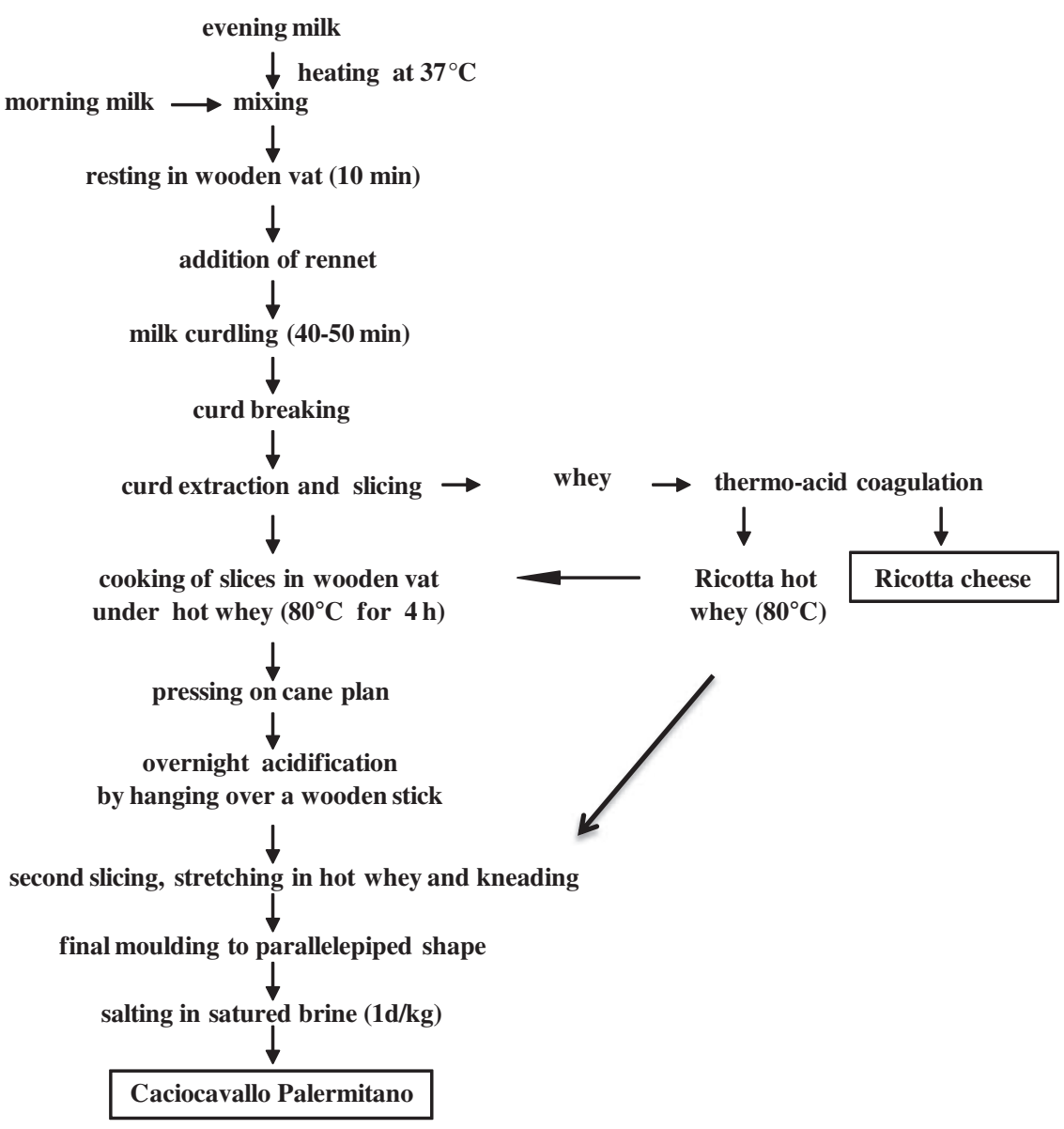

Fig. 1. Flow diagram of traditional Caciocavallo Palermitano cheese production. 
Table 1

Microbial load ${ }^{\mathrm{a}}$ of samples collected through Caciocavallo Palermitano cheese productions.

\begin{tabular}{|c|c|c|c|c|c|c|c|c|c|c|c|c|}
\hline \multirow[t]{2}{*}{ Samples } & \multicolumn{12}{|l|}{ Media $^{\mathrm{b}}$} \\
\hline & PCA-SkM $7{ }^{\circ} \mathrm{C}$ & PCA-SkM $30{ }^{\circ} \mathrm{C}$ & VRBA & KAA & РAB & $\mathrm{BP}$ & MRS & $\operatorname{M} 1730^{\circ} \mathrm{C}$ & WBAM & M17 $44^{\circ} \mathrm{C}$ & DRBC & $\mathrm{RCM}^{\mathrm{c}}$ \\
\hline \multicolumn{13}{|l|}{ Production TA } \\
\hline Bulk milk & $3.5 \pm 0.4$ & $4.0 \pm 0.6$ & $1.7 \pm 0.6$ & $2.4 \pm 0.7$ & $3.1 \pm 0.8$ & $2.5 \pm 0.4$ & $3.5 \pm 0.4$ & $3.6 \pm 0.3$ & $3.0 \pm 0.2$ & $3.5 \pm 0.3$ & $2.3 \pm 0.4$ & 0 \\
\hline Bulk milk after resting & $3.3 \pm 0.5$ & $5.0 \pm 0.6$ & $1.8 \pm 0.4$ & $2.7 \pm 0.6$ & $2.9 \pm 0.1$ & $2.2 \pm 0.6$ & $5.0 \pm 0.6$ & $5.4 \pm 0.7$ & $3.3 \pm 0.5$ & $5.3 \pm 0.6$ & $2.8 \pm 0.6$ & 0 \\
\hline Curd & $4.8 \pm 0.3$ & $5.9 \pm 0.8$ & $2.4 \pm 0.2$ & $3.5 \pm 0.2$ & $3.8 \pm 0.7$ & $3.3 \pm 0.3$ & $5.9 \pm 1.0$ & $6.3 \pm 0.4$ & $4.8 \pm 0.7$ & $6.5 \pm 0.7$ & $3.5 \pm 0.9$ & 0 \\
\hline Whey & $2.1 \pm 0.6$ & $3.9 \pm 0.8$ & $0.9 \pm 0.1$ & $1.3 \pm 0.2$ & $1.8 \pm 0.3$ & 0 & $4.1 \pm 0.1$ & $4.6 \pm 0.9$ & $3.0 \pm 0.5$ & $4.6 \pm 0.5$ & $0.8 \pm 0.1$ & n.d. \\
\hline Cooked curd & $3.7 \pm 0.2$ & $5.5 \pm 0.6$ & $2.4 \pm 0.5$ & $3.4 \pm 0.5$ & $3.0 \pm 0.6$ & 0 & $5.7 \pm 0.5$ & $6.1 \pm 0.3$ & $4.3 \pm 0.4$ & $6.3 \pm 0.7$ & $3.1 \pm 0.5$ & 0 \\
\hline Acidified curd & $3.1 \pm 0.5$ & $7.2 \pm 0.3$ & $2.7 \pm 0.4$ & $3.7 \pm 0.6$ & $2.8 \pm 0.9$ & 0 & $6.3 \pm 0.9$ & $7.4 \pm 0.6$ & $7.8 \pm 0.1$ & $8.7 \pm 0.1$ & $3.8 \pm 0.9$ & 0 \\
\hline Stretched curd & $3.3 \pm 0.5$ & $7.5 \pm 0.9$ & $2.8 \pm 0.3$ & $4.0 \pm 0.4$ & $2.5 \pm 0.2$ & 0 & $6.5 \pm 0.6$ & $7.3 \pm 0.6$ & $7.8 \pm 0.3$ & $8.4 \pm 0.1$ & $3.2 \pm 0.6$ & 0 \\
\hline Whey after stretching & n.d. & n.d. & n.d. & n.d. & n.d. & n.d. & n.d. & n.d. & $5.4 \pm 0.5$ & $5.7 \pm 0.4$ & n.d. & n.d. \\
\hline \multicolumn{13}{|l|}{ Production TB } \\
\hline Bulk milk & $5.6 \pm 0.6$ & $6.1 \pm 0.2$ & $5.0 \pm 0.5$ & $4.8 \pm 0.4$ & $4.7 \pm 0.2$ & $2.5 \pm 0.3$ & $5.4 \pm 0.2$ & $5.6 \pm 0.3$ & $4.9 \pm 0.2$ & $5.6 \pm 0.2$ & $4.3 \pm 0.2$ & 0 \\
\hline Bulk milk after resting & $5.3 \pm 0.6$ & $5.9 \pm 0.1$ & $4.7 \pm 0.9$ & $4.5 \pm 0.7$ & $4.3 \pm 0.3$ & $1.7 \pm 0.3$ & $5.6 \pm 0.2$ & $5.4 \pm 0.2$ & $4.8 \pm 0.6$ & $5.7 \pm 0.3$ & $4.5 \pm 0.6$ & 0 \\
\hline Curd & $5.0 \pm 0.5$ & $7.1 \pm 0.2$ & $5.6 \pm 0.6$ & $5.7 \pm 0.2$ & $5.5 \pm 0.3$ & $2.8 \pm 0.6$ & $6.8 \pm 0.7$ & $7.2 \pm 0.3$ & $6.3 \pm 0.3$ & $7.5 \pm 0.1$ & $5.2 \pm 0.2$ & 0 \\
\hline Whey & $3.2 \pm 0.2$ & $4.9 \pm 0.8$ & $3.5 \pm 0.2$ & $3.1 \pm 0.3$ & $3.0 \pm 0.5$ & 0 & $4.8 \pm 0.1$ & $5.6 \pm 0.9$ & $4.4 \pm 0.3$ & $5.4 \pm 0.4$ & $2.3 \pm 0.1$ & n.d. \\
\hline Cooked curd & $4.6 \pm 0.8$ & $6.9 \pm 0.6$ & $5.2 \pm 0.3$ & $5.4 \pm 0.4$ & $4.2 \pm 0.5$ & 0 & $6.5 \pm 0.4$ & $7.0 \pm 0.6$ & $6.7 \pm 0.8$ & $7.3 \pm 0.6$ & $4.2 \pm 0.4$ & 0 \\
\hline Acidified curd & $4.5 \pm 0.5$ & $8.1 \pm 0.3$ & $4.5 \pm 0.2$ & $5.3 \pm 0.9$ & $3.5 \pm 0.6$ & 0 & $7.3 \pm 0.9$ & $7.9 \pm 1.0$ & $8.1 \pm 0.1$ & $8.8 \pm 0.1$ & $4.7 \pm 0.6$ & 0 \\
\hline Stretched curd & $3.9 \pm 0.3$ & $8.0 \pm 0.6$ & $4.4 \pm 0.5$ & $5.6 \pm 0.6$ & $3.1 \pm 0.2$ & 0 & $6.9 \pm 0.4$ & $7.5 \pm 0.6$ & $7.9 \pm 0.1$ & $8.4 \pm 0.1$ & $4.1 \pm 0.2$ & 0 \\
\hline Whey after stretching & n.d. & n.d. & n.d. & n.d. & n.d. & n.d. & n.d. & n.d. & $6.0 \pm 0.4$ & $6.3 \pm 0.2$ & n.d. & n.d. \\
\hline \multicolumn{13}{|l|}{ Production SA } \\
\hline Bulk milk & $3.5 \pm 0.4$ & $4.0 \pm 0.6$ & $1.7 \pm 0.6$ & $2.4 \pm 0.7$ & $3.1 \pm 0.8$ & $2.5 \pm 0.4$ & $3.5 \pm 0.4$ & $3.6 \pm 0.3$ & $3.0 \pm 0.2$ & $3.5 \pm 0.3$ & $2.3 \pm 0.4$ & 0 \\
\hline Bulk milk + starter & $4.1 \pm 0.6$ & $6.5 \pm 0.5$ & $1.5 \pm 0.3$ & $2.3 \pm 0.4$ & $3.3 \pm 0.5$ & $2.3 \pm 0.5$ & $6.1 \pm 0.7$ & $6.6 \pm 0.7$ & $6.3 \pm 0.4$ & $6.7 \pm 0.7$ & $2.4 \pm 0.5$ & 0 \\
\hline Curd & $4.9 \pm 0.7$ & $7.6 \pm 0.4$ & $2.7 \pm 0.4$ & $3.7 \pm 0.4$ & $4.5 \pm 0.7$ & $3.4 \pm 0.4$ & $6.4 \pm 0.6$ & $7.6 \pm 0.5$ & $8.3 \pm 0.6$ & $8.8 \pm 0.5$ & $3.6 \pm 0.5$ & 0 \\
\hline Whey & $2.2 \pm 0.4$ & $4.9 \pm 0.4$ & $1.2 \pm 0.2$ & $1.1 \pm 0.3$ & $2.3 \pm 0.2$ & 0 & $4.8 \pm 0.3$ & $5.1 \pm 0.6$ & $5.3 \pm 0.5$ & $5.9 \pm 0.5$ & $1.7 \pm 0.2$ & n.d. \\
\hline Cooked curd & $4.1 \pm 0.5$ & $8.1 \pm 0.6$ & $2.9 \pm 0.6$ & $3.7 \pm 0.4$ & $3.3 \pm 0.5$ & 0 & $6.6 \pm 0.3$ & $7.1 \pm 0.4$ & $7.7 \pm 0.4$ & $8.8 \pm 0.3$ & $3.0 \pm 0.8$ & 0 \\
\hline Acidified curd & $3.9 \pm 0.3$ & $8.3 \pm 0.4$ & $3.0 \pm 0.5$ & $4.0 \pm 0.5$ & $3.2 \pm 0.3$ & 0 & $7.8 \pm 0.4$ & $8.8 \pm 0.4$ & $8.6 \pm 0.6$ & $9.3 \pm 0.6$ & $3.9 \pm 0.4$ & 0 \\
\hline Stretched curd & $3.4 \pm 0.5$ & $7.4 \pm 0.5$ & $3.0 \pm 0.5$ & $4.4 \pm 0.5$ & $3.3 \pm 0.4$ & 0 & $7.4 \pm 0.2$ & $8.4 \pm 0.4$ & $8.2 \pm 0.2$ & $8.9 \pm 0.4$ & $3.5 \pm 0.6$ & 0 \\
\hline Whey after stretching & n.d. & n.d. & n.d. & n.d. & n.d. & n.d. & n.d. & n.d. & $5.5 \pm 0.5$ & $6.2 \pm 0.6$ & n.d. & n.d. \\
\hline \multicolumn{13}{|l|}{ Production SB } \\
\hline Bulk milk & $5.6 \pm 0.6$ & $6.1 \pm 0.2$ & $5.0 \pm 0.5$ & $4.8 \pm 0.4$ & $4.7 \pm 0.2$ & $2.5 \pm 0.3$ & $5.4 \pm 0.2$ & $5.6 \pm 0.3$ & $4.9 \pm 0.2$ & $5.6 \pm 0.2$ & $4.3 \pm 0.2$ & 0 \\
\hline Bulk milk + starter & $5.3 \pm 0.4$ & $6.4 \pm 0.5$ & $4.7 \pm 0.6$ & $4.5 \pm 0.3$ & $5.1 \pm 0.5$ & $2.3 \pm 0.4$ & $6.1 \pm 0.4$ & $6.9 \pm 0.2$ & $6.7 \pm 0.2$ & $7.3 \pm 0.4$ & $4.1 \pm 0.3$ & 0 \\
\hline Curd & $6.1 \pm 0.3$ & $7.2 \pm 0.6$ & $5.7 \pm 0.4$ & $5.0 \pm 0.4$ & $5.5 \pm 0.7$ & $2.7 \pm 0.4$ & $6.7 \pm 0.3$ & $8.3 \pm 0.4$ & $8.2 \pm 0.5$ & $8.3 \pm 0.3$ & $5.4 \pm 0.3$ & 0 \\
\hline Whey & $3.9 \pm 0.4$ & $4.2 \pm 0.3$ & $2.0 \pm 0.2$ & $1.8 \pm 0.3$ & $4.0 \pm 0.2$ & 0 & $4.3 \pm 0.5$ & $5.4 \pm 0.4$ & $4.6 \pm 0.3$ & $6.2 \pm 0.5$ & $2.0 \pm 0.2$ & n.d. \\
\hline Cooked curd & $4.9 \pm 0.3$ & $7.9 \pm 0.6$ & $5.1 \pm 0.3$ & $4.8 \pm 0.5$ & $4.1 \pm 0.4$ & 0 & $6.5 \pm 0.7$ & $7.8 \pm 0.6$ & $8.0 \pm 0.4$ & $8.1 \pm 0.3$ & $3.9 \pm 0.3$ & 0 \\
\hline Acidified curd & $4.4 \pm 0.1$ & $8.0 \pm 0.4$ & $4.7 \pm 0.5$ & $4.8 \pm 0.4$ & $3.9 \pm 0.6$ & 0 & $7.5 \pm 0.7$ & $8.5 \pm 0.5$ & $8.4 \pm 0.5$ & $9.4 \pm 0.5$ & $4.1 \pm 0.5$ & 0 \\
\hline Stretched curd & $4.1 \pm 0.6$ & $7.9 \pm 0.5$ & $4.2 \pm 0.3$ & $5.1 \pm 0.5$ & $3.6 \pm 0.5$ & 0 & $6.9 \pm 0.4$ & $7.4 \pm 0.3$ & $7.8 \pm 0.2$ & $8.7 \pm 0.4$ & $3.4 \pm 0.3$ & 0 \\
\hline Whey after stretching & n.d. & n.d. & n.d. & n.d. & n.d. & n.d. & n.d. & n.d. & $5.4 \pm 0.5$ & $5.9 \pm 0.4$ & n.d. & n.d. \\
\hline \multicolumn{13}{|l|}{ Statistical significance $^{\mathrm{d}}$} \\
\hline Farm $(F)$ & $* * *$ & $* * *$ & $* * *$ & $* * *$ & $* * *$ & $*$ & $* * *$ & $* * *$ & $* * *$ & $* * *$ & $* * *$ & \\
\hline Production (P) & $* * *$ & $* * *$ & NS & $*$ & $* * *$ & NS & $* * *$ & $* * *$ & $* * *$ & $* * *$ & NS & \\
\hline Sample (S) & $* * *$ & $* * *$ & $* * *$ & $* * *$ & $* * *$ & $* * *$ & $* * *$ & $* * *$ & $* * *$ & $* * *$ & $* * *$ & \\
\hline $\mathrm{F}^{*} \mathrm{P}^{*} \mathrm{~S}$ & ** & $* * *$ & $* * *$ & $*$ & NS & NS & $* *$ & $* * *$ & $* * *$ & $* * *$ & $* *$ & \\
\hline
\end{tabular}

n.d., not determined.

Results indicate mean values \pm S.D. of six plate counts (carried out in duplicate for three independent productions).

${ }^{\text {a }}$ Log cfu $\mathrm{mL}^{-1}$ for milk and whey samples, Log cfu $\mathrm{g}^{-1}$ for curds.

b Abbreviations: PCA-SkM $7{ }^{\circ} \mathrm{C}$, plate count agar added with skimmed milk incubated at $7{ }^{\circ} \mathrm{C}$ for total psychrotrophic counts; PCA-SkM $30{ }^{\circ} \mathrm{C}$, plate count agar added with skimmed milk incubated at $30^{\circ} \mathrm{C}$ for total mesophilic counts; VRBA, violet red bile agar for coliforms; KAA, kanamycin aesculin azide agar for enterococci; PAB, Pseudomonas agar base for pseudomonads; BP, Baird Parker for CPS; MRS, de Man-Rogosa-Sharpe agar for mesophilic rod LAB; M17 $30{ }^{\circ} \mathrm{C}$, medium 17 agar incubated at $30{ }^{\circ} \mathrm{C}$ for mesophilic coccus LAB; M17 $44{ }^{\circ} \mathrm{C}$, medium 17 agar incubated at $44^{\circ} \mathrm{C}$ for thermophilic coccus LAB; WBAM, whey-based agar medium for thermophilic rod LAB; DRBC, dichloran rose bengal chloramphenicol agar for yeast; RCM, reinforced clostridial medium for clostridia.

c As estimated by MPN.

d P value: ***, $\mathrm{P}<0.001$; **, $\mathrm{P}<0.01$; *, $\mathrm{P}<0.05$; NS, not significant.

(TPC) on PCA-SkM, incubated aerobically at $7^{\circ} \mathrm{C}$ for $7 \mathrm{~d}$; coliforms on violet red bile agar (VRBA), incubated aerobically at $37^{\circ} \mathrm{C}$ for $24 \mathrm{~h}$; enterococci on kanamycin aesculin azide (KAA) agar, incubated aerobically at $37^{\circ} \mathrm{C}$ for $24 \mathrm{~h}$; pseudomonads on Pseudomonas agar base (PAB) supplemented with $10 \mathrm{mg} \mathrm{mL}^{-1}$ cetrimide fucidin, incubated aerobically at $20^{\circ} \mathrm{C}$ for $48 \mathrm{~h}$; coagulase positive staphylococci (CPS) on Baird Parker (BP) with added RPF supplement, incubated aerobically at $37^{\circ} \mathrm{C}$ for $48 \mathrm{~h}$; mesophilic rod LAB on de Man-Rogosa-Sharpe (MRS) agar, acidified at pH 5.4 with lactic acid $\left(5 \mathrm{~mol} \mathrm{~L}^{-1}\right)$, incubated anaerobically at $30^{\circ} \mathrm{C}$ for $48 \mathrm{~h}$; mesophilic cocci LAB on M17 agar, incubated anaerobically at $30^{\circ} \mathrm{C}$ for $48 \mathrm{~h}$; thermophilic cocci LAB on M17 agar, incubated anaerobically at $44^{\circ} \mathrm{C}$ for $4 \mathrm{~d}$; yeasts on dichloran rose bengal chloramphenicol (DRBC) agar, incubated aerobically at $25^{\circ} \mathrm{C}$ for $48 \mathrm{~h}$. Thermophilic rod LAB were counted, after anaerobic incubation at $44^{\circ} \mathrm{C}$ for $4 \mathrm{~d}$, on whey-based agar medium (WBAM) prepared as follows: non-acidified cow's milk whey, collected after curd separation during a previous Caciocavallo Palermitano cheese production, was sterilized $\left(15 \mathrm{~min}\right.$ at $121^{\circ} \mathrm{C}$ ), centrifuged $(10.000 \mathrm{~g}$ for $15 \mathrm{~min})$ for clarification and re-sterilized; the whey was then mixed (ratio 10:3) into a sterilized solution containing peptone $(1 \% \mathrm{w} / \mathrm{v})$, yeast extract $(0.4 \% \mathrm{w} / \mathrm{v})$ and agar $(5 \% \mathrm{w} / \mathrm{v})$. Before autoclaving, both solutions were adjusted for $\mathrm{pH}$ at 5.4 with lactic acid $\left(5 \mathrm{~mol} \mathrm{~L}^{-1}\right)$. Clostridial content was estimated by the most probable number (MPN) technique using a $3 \times 3$ scheme: undiluted samples and decimal dilutions were pasteurized at $85^{\circ} \mathrm{C}$ for $15 \mathrm{~min}$ and inoculated into reinforced clostridial medium (RCM) supplemented with $1.4 \%$ (v/v) Na-lactate (Merck, Darmstadt, Germany); after that, test tubes were sealed with paraffin:vaseline (1:6) and incubated at $37^{\circ} \mathrm{C}$ for $7 \mathrm{~d}$. All media were purchased from Oxoid (Basingstoke, UK).

Lamb rennet paste (strength $1: 10,000$ ), used for both traditional and standard cheese productions $\left(0.4 \mathrm{~g} \mathrm{~L}^{-1}\right)$, as well as the dried starter culture, used only for standard cheese making $\left(0.08 \mathrm{~g} \mathrm{~L}^{-1}\right)$, were analyzed for LAB content using the above four media incubated in the conditions previously reported. 
In order to ascertain the safety of the wooden vat with regards to the presence of two pathogens, Salmonella spp. and L. monocytogenes were also investigated. The two pathogens were searched by adapting the methodology described by Mucchetti et al. (2008), applying the pre-enrichment procedure on the cotton swabs streaked onto the surface of the vat.

\subsection{Isolation of $L A B$ and phenotypic grouping}

After growth, at least 4 colonies for each different morphology observed were picked up from count plates of presumptive LAB and transferred to the corresponding broth media. Cultures from WBAM were inoculated into MRS broth medium. The isolates were purified by successive sub-culturing. The purity of the cultures and cell morphology were checked microscopically. Gram-positive (Gregersen, 1978) and catalase negative [determined by transferring fresh colonies from a Petri dish to a glass slide and adding $5 \%(\mathrm{w} / \mathrm{v}) \mathrm{H}_{2} \mathrm{O}_{2}$ ] isolates were stored in glycerol at $-80^{\circ} \mathrm{C}$ until further experimentations.

In order to perform a first clustering of $\mathrm{LAB}$, rod and coccal-shaped cultures were tested separately. Rod LAB were grouped according to the morphological cell aspect, growth at 15 and $45^{\circ} \mathrm{C}$ and $\mathrm{CO}_{2}$ production from glucose. Coccus isolates were grouped also on the basis of their growth at pH 9.2 and in the presence of $6.5 \%(\mathrm{w} / \mathrm{v}) \mathrm{NaCl}$ (Corsetti et al., 2001).

\subsection{DNA extraction, genotypic differentiation and identification of $L A B$}

Cell lysis for DNA extraction was performed by the Instagene Matrix kit (Bio-Rad, Hercules, CA) as described by the manufacturer. Crude cell extracts were used as a template for PCR reactions.

Strain differentiation was performed by random amplification of polymorphic DNA-PCR (RAPD-PCR) analysis in a $25-\mu \mathrm{L}$ reaction mix using single primers M13 (Stenlid et al., 1994), AB111, and AB106 (van den Braak et al., 2000). Amplifications were performed by means of T1 Thermocycler (Biometra, Göttingen, Germany) applying the conditions reported by Zapparoli et al. (1998) for primer M13 and those reported by the reference paper for primers AB111 and AB106. PCR products were separated by electrophoresis on $1.5 \%(\mathrm{w} / \mathrm{v})$ agarose gel (Gibco BRL, Cergy Pontoise, France) and visualized by UV transillumination after staining with ethidium bromide $\left(0.5 \mu \mathrm{g} \mathrm{mL}{ }^{-1}\right)$. A deoxyribonucleic acid ladder $1 \mathrm{~Kb}$ (Invitrogen, Carlsbad, CA) was used as a molecular size marker. RAPD-PCR profiles were analyzed with the pattern analysis software package Gel Compar Version 4.1 (Applied Maths, Kortrijk, Belgium). Calculation of similarities of band profiles was based on the Pearson product moment correlation coefficient. Dendrograms were obtained by means of the unweighted pair group method using an arithmetic average clustering algorithm.

Genotypic identification of LAB with different RAPD-PCR profiles was carried out by $16 \mathrm{~S}$ rRNA gene sequencing. PCR reactions were performed as described by Weisburg et al. (1991). DNA fragments were visualized and the amplicons of about 1600 bp were purified by the QIAquick purification kit (Quiagen S.p.a., Milan, Italy) and sequenced using the same primers employed for PCR amplification. DNA sequencing reactions were performed by PRIMM (Milan, Italy). The sequences were compared by a BLAST search in GenBank/EMBL/DDBJ database (Altschul et al., 1997).

\section{5. $\mathrm{pH}$ and total titratable acidity determination}

Samples of cooked curds and acidified curds were analyzed for $\mathrm{pH}$ with a portable pH meter (Knick Portamess 910, Berlin, Germany) connected to a Cheesetrode (Hamilton Co., Reno, NV, USA) electrode. Total titratable acidity (TTA), expressed as mg lactic acid/100 g of curd, was determined according to AOAC method 920.124 (2005).

\subsection{Statistical analysis}

Data were analyzed using GLM procedure of the program SAS 2004, version 9.1.2 (Statistical Analysis System Institute Inc., Cary, NC, USA).

The microbiological data were analyzed by a model including the effects of farm $(F=A, B)$, cheese production $(P=$ traditional, standard), sample type ( $S=1$ to 8 ), and all their interaction $\mathrm{F}^{*} \mathrm{P}^{*} \mathrm{~S}$; the Student "t" test was used for means comparisons. The model used to evaluate differences of $\mathrm{pH}$ and TTA included the effects $\mathrm{F}, \mathrm{P}$ and $F^{*}$ P. Significance level was $\mathrm{P}<0.05$.

\section{Results}

\subsection{Microbiological analysis}

The viable counts of the 12 microbial groups investigated in this study are reported in Table 1. In general, the effects of farm, cheese making condition and sample type affected significantly the development of most groups.

The bulk milk from the two farms (A and B) was characterized by different levels of microorganisms. Butyric clostridia were never detected (RCM). Except for CPS, found at the same level for both milk matrices, bulk milk B showed higher counts than bulk milk A. In both matrices, the bacterial groups found at the highest numbers were LAB. Furthermore, both bulk milks showed a ratio between mesophilic coccus and rod LAB close to 1 , whereas, the counts for thermophilic rod LAB were lower than those for thermophilic cocci.

In traditional cheese productions (TA and TB), after $\mathrm{Ca} .10 \mathrm{~min}$ of resting in the wooden vat, cell counts of bulk milk A changed for some bacterial groups, in particular, mesophilic rod and coccus LAB and thermophilic coccus LAB increasing significantly $(P<0.001)$ their concentration. This trend was not observed for bulk milk $B$, whose LAB did not increase in levels in the same period. The results for the other microbial groups were almost unchanged after milk resting. These results could be explained by the counts obtained with sterile swabs streaked on the empty wooden vat before cheese production (Table 2 ). The results showed that the microorganisms

Table 2

Microbial loads ( $\log \mathrm{cfu} \mathrm{cm}^{-2}$ ) a of internal surfaces of wooden vat used for milk curdling.

\begin{tabular}{llll}
\hline Media $^{\text {b }}$ & Base & Side & Base/side \\
\hline PCA-SkM $7{ }^{\circ} \mathrm{C}$ & $3.0 \pm 0.8$ & $2.2 \pm 0.6$ & $3.4 \pm 0.2$ \\
PCA-SkM $30{ }^{\circ} \mathrm{C}$ & $5.9 \pm 0.5$ & $5.1 \pm 0.3$ & $6.5 \pm 0.2$ \\
VRBA & 0 & 0 & $0.7 \pm 0.3$ \\
KAA & 0 & 0 & $2.6 \pm 0.2$ \\
PAB & $0.6 \pm 0.3$ & 0 & $1.8 \pm 0.5$ \\
BP & 0 & 0 & 0 \\
MRS & $4.0 \pm 0.5$ & $3.7 \pm 0.5$ & $5.5 \pm 0.1$ \\
M17 30 ${ }^{\circ} \mathrm{C}$ & $6.1 \pm 0.8$ & $5.3 \pm 0.4$ & $6.7 \pm 0.9$ \\
WBAM & $6.1 \pm 0.7$ & $4.9 \pm 0.4$ & $6.4 \pm 0.5$ \\
M17 44 ${ }^{\circ} \mathrm{C}$ & $5.6 \pm 0.4$ & $4.7 \pm 0.2$ & $6.3 \pm 0.3$ \\
DRBC & $2.6 \pm 0.4$ & $2.3 \pm 0.7$ & $2.7 \pm 0.1$ \\
RCM & n.d. & n.d. & n.d. \\
\hline
\end{tabular}

Results indicate mean values \pm S.D. of twelve plate counts (carried out in duplicate for six independent productions).

a Log cfu per $\mathrm{cm}^{2}$.

b Abbreviations: PCA-SkM $7{ }^{\circ} \mathrm{C}$, plate count agar added with skimmed milk incubated at $7{ }^{\circ} \mathrm{C}$ for total psychrotrophic counts; PCA-SkM $30^{\circ} \mathrm{C}$, plate count agar added with skimmed milk incubated at $30^{\circ} \mathrm{C}$ for total mesophilic counts; VRBA, violet red bile agar for coliforms; KAA, kanamycin aesculin azide agar for enterococci; PAB, Pseudomonas agar base for pseudomonads; BP, Baird Parker for CPS; MRS, de Man-Rogosa-Sharpe agar for mesophilic rod LAB; M17 $30{ }^{\circ} \mathrm{C}$, medium 17 agar incubated at $30^{\circ} \mathrm{C}$ for mesophilic coccus LAB; M17 $44^{\circ} \mathrm{C}$, medium 17 agar incubated at $44^{\circ} \mathrm{C}$ for thermophilic coccus LAB; WBAM, whey-based agar medium for thermophilic rod LAB; DRBC, dichloran rose bengal chloramphenicol agar for yeast; RCM, reinforced clostridial medium for clostridia.

c As estimated by MPN. 
mainly found on those surfaces were LAB, while the other groups were less represented or absent.

The same bulk milks were used to carry out cheese productions under standard conditions (SA and SB), by the use of stainless dairy equipment and addition of commercial dried starter cultures. After inoculation of starters, LAB and TMC counts increased. Both cheese productions were then characterized by similar levels of LAB; the highest numbers were estimated for thermophilic $\mathrm{LAB}$ cocci.

After curd cooking, the levels of $\mathrm{LAB}$, including enterococci, as well as coliform bacteria, did not greatly vary for all four productions. TPC, pseudomonads and yeasts decreased significantly $(\mathrm{P}<0.01)$ their cell counts, while CPS disappeared. The acidification of curd resulted in higher concentrations of almost all groups except pseudomonads, which remained at the same level or showed a negligible decrement in number. In particular, the acidified curds of the four productions were dominated by thermophilic LAB cocci. A similar trend was observed after stretching.

Regarding whey samples, they showed comparable levels of the different microbial groups at the time of curd separation and after stretching.

Lamb rennet was found to be contaminated by LAB; in particular, $5.7 \pm 0.4 \mathrm{Log}_{\mathrm{cfu} \mathrm{g}} \mathrm{g}^{-1}$ of mesophilic rods, $4.4 \pm 0.3 \mathrm{Log} \mathrm{cfu} \mathrm{g}^{-1}$ of thermophilic rods, $6.4 \pm 0.5 \mathrm{Log}_{\mathrm{cfu}} \mathrm{g}^{-1}$ of mesophilic cocci and $5.4 \pm 0.5$ $\log \mathrm{cfu} \mathrm{g}^{-1}$ of thermophilic cocci. Dried starter culture contained $11.6 \pm 0.4 \mathrm{Log}_{\mathrm{cfu} \mathrm{g}} \mathrm{g}^{-1}$ of thermophilic LAB cocci, but $8.7 \pm 0.6 \mathrm{Log}$

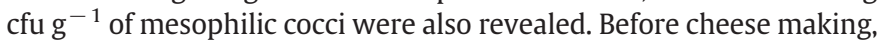
the internal surfaces of the stainless steel vat did not host any LAB.

The safety of the wooden vat was confirmed by the absence of Salmonella spp. and L. monocytogenes.

\subsection{Isolation and grouping of $L A B$}

On the basis of appearance, about 4 colonies per morphology were isolated from each medium used for LAB counts (MRS, WBAM, M17$30{ }^{\circ} \mathrm{C}$ and $\mathrm{M} 17-44^{\circ} \mathrm{C}$ ), at the highest dilutions of the samples. Seventy-two colonies were collected from raw bulk milk, 24 from the wooden vat surfaces, 764 from samples of the traditional productions and 444 from samples of the standard productions, forming a total of 1304 cultures which were propagated in broth media corresponding to those used for counts, applying the same incubation conditions. All cultures were subjected to microscopic inspection and separated as 1139 cocci and 165 rods. After Gram characterization and catalase testing, 1109 cocci and 163 rods were still considered presumptive LAB cultures, as being Gram-positive and catalase-negative.

All cultures were tested for growth temperature and $\mathrm{CO}_{2}$ production from glucose, whereas cocci LAB were also evaluated for growth at $\mathrm{pH} 9.2$ and in the presence of $\mathrm{NaCl} 6.5 \%(\mathrm{w} / \mathrm{v})$. The phenotypic characterization allowed the separation of the 1272 LAB cultures into seven groups (Table 3 ), three for rods and four for cocci. The most numerous groups were III and IV with 437 and 439 isolates, respectively. These groups together included about the $69 \%$ of presumptive LAB isolated during Caciocavallo Palermitano cheese production. The remaining $31 \%$ of isolates were divided into five groups well differentiated from one another on the basis of the combinations of the phenotypic characters considered. However, the unequivocal determination of the fermentative metabolism of LAB included in the group $V$ needed the evaluation of their growth in presence of pentose sugars, which showed their facultative heterofermentative metabolism.

\section{3. $R A P D-P C R$}

About $30 \%$ of the isolates of each phenotypic group, forming a total of 380 isolates, were selected from the samples collected through cheese productions and subjected to RAPD analysis using primer M13 (results not shown). The above isolates were divided into 34 main clusters ( $80 \%$ similarity level) for the seven phenotypic groups: one cluster for group I, six for group II, 13 for group III, 9 for group IV, one for group V, one for group VI and three for group VII. One isolate per cluster was further processed with primers AB111 and AB106 which confirmed that the isolates analyzed constituted 34 different strains.

\subsection{Identification of $L A B$}

All 34 strains (including one strain from the dried starter preparation) were identified by $16 \mathrm{~S}$ rRNA gene sequencing. The BLAST search shared a percentage of identity with sequences available in the NCBI database of at least $97 \%$, which is considered the minimum level of similarity for $16 \mathrm{~S}$ rRNA genes of two strains belonging to the same species (Stackebrandt and Goebel, 1994), for 33 strains, while one strain showed a lower similarity and was recognized only at genus (Leuconostoc) level (Table 4). The strain isolated from the starter culture preparation was identified as $\mathrm{S}$. thermophilus.

\subsection{Species and strain distribution}

Only two (Enterococcus faecalis and S. thermophilus) out of the 15 species found during the traditional Caciocavallo Palermitano cheese manufactures were clearly found associated with the different steps of production (Table 4). However, E. faecalis was also isolated from raw milk, whereas S. thermophilus was not. The last species was identified among the isolates of wooden vat origin and, then, from each sample collected during the whole production line. S. thermophilus and $E$. faecalis were also present in the acidified curd. Microbial counts (Table 1) showed that thermophilic LAB cocci were more concentrated than enterococci by about 3 or 5 orders of magnitude for TB and TA, respectively.

An interesting finding was provided by the analysis of RAPD profiles of the strains belonging to the species $S$. thermophilus. Six different strains (Fig. 2, lanes 1-6) were isolated from the wooden vat used for traditional cheese making. Four of these strains (Fig. 2, lanes 1, 2, 3 and 5) were isolated from all samples analyzed, from raw milk after resting in

Table 3

Phenotypic grouping of LAB isolates collected through traditional and standard Caciocavallo Palermitano cheese production.

\begin{tabular}{|c|c|c|c|c|c|c|c|}
\hline \multirow[t]{2}{*}{ Characters } & \multicolumn{7}{|l|}{ Clusters } \\
\hline & $\mathrm{I}(\mathrm{n}=32)$ & II $(\mathrm{n}=201)$ & III $(n=437)$ & $\operatorname{IV}(\mathrm{n}=439)$ & $V(n=32)$ & VI $(n=29)$ & VII $(n=102)$ \\
\hline Morphology & Coccus & Coccus & Coccus & Coccus & Rod & Rod & Rod \\
\hline \multicolumn{8}{|l|}{ Growth: } \\
\hline $15^{\circ} \mathrm{C}$ & + & + & + & - & + & + & + \\
\hline $45^{\circ} \mathrm{C}$ & - & - & + & + & - & - & + \\
\hline pH 9.2 & - & + & + & - & n.d. & n.d. & n.d. \\
\hline $6.5 \% \mathrm{NaCl}$ & + & - & + & - & n.d. & n.d. & n.d. \\
\hline $\mathrm{CO}_{2}$ from glucose & + & - & - & - & - & + & + \\
\hline Growth in presence of pentose carbohydrates & n.d. & n.d. & n.d. & n.d. & + & n.d. & n.d. \\
\hline
\end{tabular}

n.d. not determined. 
Table 4

Identification and distribution of LAB strains through traditional Caciocavallo Palermitano cheese production.

\begin{tabular}{|c|c|c|c|c|c|c|c|c|c|c|c|c|}
\hline \multirow[t]{2}{*}{ Strain } & \multirow{2}{*}{$\begin{array}{l}\text { Phenotypic } \\
\text { group }\end{array}$} & \multirow[t]{2}{*}{ Acc. No. } & \multirow[t]{2}{*}{ Species } & \multicolumn{9}{|c|}{ Matrices } \\
\hline & & & & $\begin{array}{l}\text { Bulk } \\
\text { milk }\end{array}$ & $\begin{array}{l}\text { Wooden vat } \\
\text { surfaces }\end{array}$ & $\begin{array}{l}\text { Bulk milk after } \\
\text { resting }\end{array}$ & Curd & Whey & $\begin{array}{l}\text { Cooked } \\
\text { curd }\end{array}$ & $\begin{array}{l}\text { Acidified } \\
\text { curd }\end{array}$ & $\begin{array}{l}\text { Stretched } \\
\text { curd }\end{array}$ & $\begin{array}{l}\text { Whey after } \\
\text { stretching }\end{array}$ \\
\hline FMA108 & III & HQ721253 & E. casseliflavus & & घ & 口 & & & & & & \\
\hline FMA8 & III & HQ721252 & E. durans & $\mathbf{\square}$ & & $\mathbf{\square}$ & & & & & & \\
\hline FMA444 & III & HQ721272 & E. faecalis & $\mathbf{\square}$ & & $\mathbf{\square}$ & $\boldsymbol{\square}$ & $\mathbf{\square}$ & $\square$ & $\mathbf{\square}$ & $\mathbf{\square}$ & \\
\hline FMA463 & III & HQ721256 & E. faecalis & $\mathbf{\square}$ & & $\mathbf{\square}$ & $\boldsymbol{\square}$ & & & & $\mathbf{\square}$ & \\
\hline FMA604 & III & HQ721258 & E. faecalis & $\mathbf{\square}$ & & $\mathbf{\square}$ & $\boldsymbol{\square}$ & & घ & 口 & 口 & \\
\hline FMA713 & III & HQ721273 & E. faecalis & $\mathbf{\square}$ & & $\mathbf{\square}$ & $\boldsymbol{\square}$ & $\mathbf{\square}$ & घ & $\mathbf{\square}$ & & \\
\hline FMA721 & III & HQ721277 & E. faecalis & & घ & $\mathbf{\square}$ & $\boldsymbol{\square}$ & & घ & & $\mathbf{\square}$ & \\
\hline FMA797 & III & HQ721260 & E. faecalis & $\mathbf{\square}$ & & $\mathbf{\square}$ & $\boldsymbol{\square}$ & $\mathbf{\square}$ & 口 & 口 & $\mathbf{\square}$ & \\
\hline MOB6 & III & n.d. & E. faecalis & & 口 & 口 & $\boldsymbol{\square}$ & $\mathbf{\square}$ & 口 & $\mathbf{\square}$ & & \\
\hline FMA505 & III & HQ721257 & E. faecium & & घ & $\mathbf{\square}$ & & & & & & \\
\hline FMA288 & III & HQ721269 & E. gallinarum & & च & $\mathbf{n}$ & & & & & & \\
\hline FMA192 & III & HQ721268 & E. italicus & & घ & $\mathbf{\square}$ & & & & & & \\
\hline FMA295 & III & HQ721276 & E. italicus & & घ & & & & & & & \\
\hline FMA224 & V & HQ721246 & Lb. alimentarius & $\mathbf{\square}$ & & & & & & & & \\
\hline FMA205 & VI & HQ721262 & Lb. parabuchneri & 口 & & & & & & & & \\
\hline FMA395 & II & HQ721245 & Lc. garvieae & $\mathbf{\square}$ & & $\mathbf{\square}$ & $\boldsymbol{\square}$ & & घ & & & \\
\hline FMA401 & II & HQ721279 & Lc. garvieae & $\mathbf{\square}$ & & $\mathbf{\square}$ & $\boldsymbol{\square}$ & & & 口 & $\mathbf{\square}$ & \\
\hline FMA809 & II & HQ721265 & Lc. garvieae & $\mathbf{\square}$ & & $\mathbf{E}$ & $\boldsymbol{\square}$ & & $\mathbf{\square}$ & $\mathbf{\square}$ & & \\
\hline FMA187 & II & HQ721254 & Lc. lactis spp. lactis & 口 & & घ & $\boldsymbol{\square}$ & $\mathbf{a}$ & & & & \\
\hline FMA558 & II & HQ721275 & Lc. lactis spp. lactis & $\mathbf{\square}$ & & & & & & & & \\
\hline MOB4 & II & HQ721267 & Lc. lactis spp. lactis & 口 & & & & & & & & \\
\hline FMA6 & I & n.d. & Leuconostoc spp. & $\mathbf{\square}$ & & $\mathbf{\square}$ & & & घ & & & \\
\hline FMA766 & IV & HQ721264 & S. bovis & $\mathbf{\square}$ & & & & & & & & \\
\hline FMA830 & IV & HQ721250 & S. macedonicus & & & & & & $\mathbf{\square}$ & & & $\mathbf{\square}$ \\
\hline FMA196 & IV & HQ721271 & S. thermophilus & & $\mathbf{\square}$ & $\mathbf{E}$ & $\boldsymbol{\square}$ & $\mathbf{0}$ & $\mathbf{\square}$ & $\mathbf{\square}$ & $\mathbf{\square}$ & $\mathbf{\square}$ \\
\hline FMA327 & IV & HQ721274 & S. thermophilus & & घ & $\mathbf{\square}$ & & घ & घ & $\mathbf{\square}$ & $\mathbf{\square}$ & $\mathbf{\square}$ \\
\hline FMA617 & IV & HQ721278 & S. thermophilus & & 口 & $\mathbf{n}$ & $\boldsymbol{\square}$ & $\mathbf{\square}$ & & घ & $\mathbf{\square}$ & \\
\hline FMA701 & IV & HQ721263 & S. thermophilus & & घ & $\mathbf{\square}$ & $\boldsymbol{\square}$ & $\mathbf{\square}$ & घ & & & \\
\hline FMA808 & IV & HQ721249 & S. thermophilus & & 口 & 口 & $\boldsymbol{\square}$ & $\mathbf{\square}$ & 口 & & & \\
\hline FMA854 & IV & HQ721261 & S. thermophilus & & घ & घ & $\square$ & $\mathbf{\square}$ & घ & $\mathbf{\square}$ & $\mathbf{\square}$ & $\mathbf{\square}$ \\
\hline FMA204 & VII & HQ721255 & W. paramesenteroides & $\mathbf{\square}$ & & घ & $\mathbf{\square}$ & & $\mathbf{\square}$ & & & \\
\hline FMA246 & VII & HQ721270 & W. paramesenteroides & & $\mathbf{\square}$ & $\mathbf{n}$ & $\boldsymbol{\square}$ & & & & & \\
\hline FMA539 & VII & HQ721247 & W. paramesenteroides & $\mathbf{\square}$ & & $\mathbf{a}$ & $\boldsymbol{\square}$ & & & & & \\
\hline
\end{tabular}

n.d. not deposited.

the wooden vat till stretched curd collected from TA and TB. In order to exclude a possible LAB contamination by lamb rennet, RAPD profiles of $S$. thermophilus were compared to those of thermophilic LAB cocci isolated from the lamb rennet itself: the RAPD patterns (Fig. 2, lanes 7-9) were not superimposable.

The contamination of the traditional cheese making trials by $S$. thermophilus strains originating from commercial thermophilic LAB starter culture, used for standard cheese manufactures (SA and SB), was also excluded by RAPD profile comparison (Fig. 2, lanes 10-12). Both SA and SB productions were dominated by a single S. thermophilus strain.

\section{6. $\mathrm{pH}$ and TTA analysis}

In order to estimate chemical differences among traditional and standard Caciocavallo Palermitano cheese productions, the curds obtained from both cheese manufactures were analyzed for $\mathrm{pH}$ and TTA before (cooked curds) and after acidification (acidified curds). The results, reported in Table 5, showed that both traditional and standard productions were characterized by similar $\mathrm{pH}$ and TTA values after cooking, as well as after acidification. The last data demonstrated that the indigenous $S$. thermophilus strains of wooden vat origin resulted in the acidification of the cooked curds comparable to that due to the commercial starter culture preparation. No statistical differences in acidification were seen in the curd between traditional and standard cheese making carried out with milks A and B.

\section{Discussion}

Caciocavallo Palermitano cheese is a Sicilian dairy product being more and more appreciated by consumers attracted by traditional foods. This product does not enjoy a guaranteed quality status and the recent increase in demand has resulted in some variability in the production process. The industrial dairy factories that transform high volumes of milk are producing Caciocavallo Palermitano cheese with the addition of commercial starter LAB and employing stainless steel equipment. This trend is actually going in contradiction with the protection of traditional productions. In order to enhance the above production, this work was performed to evaluate the influence of the wooden dairy plant equipment on the microbiological characteristics of curd to be transformed into cheese.

The quality of milk strongly depends on the microbial loading and is influenced by technological parameters such as cooling and holding temperature, as well as storage time (Heeschen, 1996; Slaghuis, 1996; Murphy and Boor, 2000). However, the dairy equipment may play a defining role in enriching the bulk milk with certain microbial groups. Recently, it has been demonstrated that the wooden surfaces of the vats used for the production of Ragusano PDO cheese are contaminated by microorganisms, in particular LAB, with concentrations varying between $10^{3}$ and $10^{6} \mathrm{CFU}$ per square centimeter (Licitra et al., 2007; Lortal et al., 2009). Although other equipment, such as wooden shelves used for ripening, maybe the source of living microorganisms (Mariani et al., 2007), the equipment playing a key role during cheese production is undoubtedly the vat hosting milk. For this reason, in the present work the internal surfaces of the wooden vat were analyzed for the same microbial groups counted for milk, curd and whey samples. The results showed that $\mathrm{LAB}$ dominated the surfaces of the wooden vat, but low levels of coliforms, pseudomonads, enterococci and yeasts were also detected. The levels of LAB on the wooden vat surfaces were enough to influence the microbial counts of the bulk milk A, but not those of the bulk milk B, which already hosted high loads of microorganisms. No CPS were found, thus confirming the 


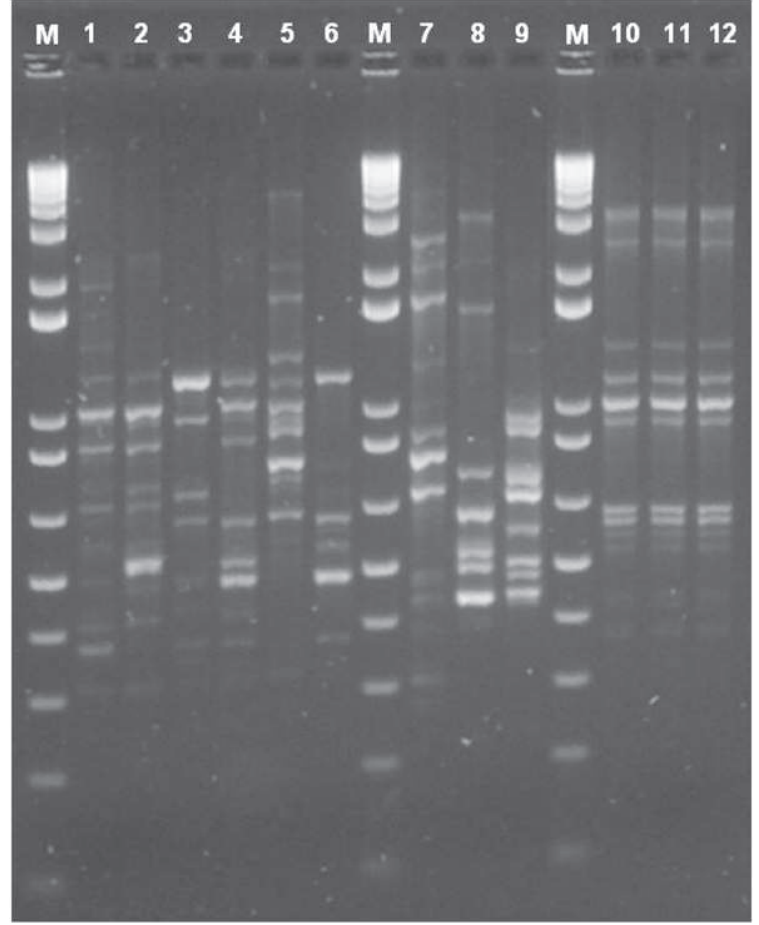

Fig. 2. RAPD-PCR profiles of $L A B$ associated with traditional and standard Caciocavallo Palermitano cheese productions obtained with primer M13. Lanes M, 1-kb DNA molecular size markers (Invitrogen). Lanes 1-6, S. thermophilus strains isolated from traditional Caciocavallo Palermitano cheese productions: 1, FMA196; 2, FMA327; 3, FMA617; 4, FMA701; 5, FMA854; FMA808. Lanes 7-9, lamb rennet thermophilic coccus LAB strains: 7, FMA2001; 8, FMA2028; 9, FMA2019. Lanes 10-12, S. thermophilus starter strain: 10, isolated from commercial freeze-dried starter culture preparation; 11 , isolated from standard Caciocavallo Palermitano cheese production A; 12, isolated from standard Caciocavallo Palermitano cheese production $\mathrm{B}$.

observation of Lortal et al. (2009) that, from an hygienic point of view, the wooden vat is safe since it does not host pathogenic species.

Different technological factors adopted during Caciocavallo Palermitano cheese production may prevent the development of pathogenic bacteria in the wooden vat: curd is cooked at temperatures above $80^{\circ} \mathrm{C}$ under whey and, the next day, the acidified curd is stretched under hot whey $\left(80^{\circ} \mathrm{C}\right)$. Other parameters contributing to this phenomenon of protection from pathogens are the competition for nutrients and the sudden $\mathrm{pH}$ lowering determined by LAB that ferment lactose from the residual whey in the wooden vat. In fact, the vat is washed with hot whey by means of a brush and it is not treated with detergents and sanitizing agents.

The undesired pseudomonads decreased in number and the CPS completely disappeared during milk transformation, through the

Table 5

Values of $\mathrm{pH}$ and total titratable acidity of curds produced during traditional and standard Caciocavallo Palermitano cheese manufacturing.

\begin{tabular}{lll}
\hline Samples & $\mathrm{pH}$ & $\mathrm{TTA}(\mathrm{mg} / 100 \mathrm{~g})$ \\
\hline TA-cooked curd & $5.65 \pm 0.06$ & $117 \pm 34$ \\
TA-acidified curd & $5.13 \pm 0.08$ & $359 \pm 25$ \\
TB-cooked curd & $5.62 \pm 0.05$ & $126 \pm 28$ \\
TB-acidified curd & $5.19 \pm 0.09$ & $386 \pm 13$ \\
SA-cooked curd & $5.70 \pm 0.04$ & $136 \pm 41$ \\
SA-acidified curd & $5.07 \pm 0.08$ & $368 \pm 13$ \\
SB-cooked curd & $5.62 \pm 0.08$ & $136 \pm 24$ \\
SB-acidified curd & $5.10 \pm 0.07$ & $378 \pm 25$ \\
\hline
\end{tabular}

Abbreviations are as follows: TTA, total titratable acidity; TA, traditional production A; $\mathrm{TB}$, traditional production $\mathrm{B}$; SA, standard production A; SB, standard production $B$. Results indicate mean value \pm S.D. of three independent measurements. stretched curd. The results for psychrotrophic bacteria were in the same range and showed a similar behavior to that found for pseudomonads. The most frequently reported psychrotrophic bacteria of raw milk are generally reported to be pseudomonads (Wiedmann et al., 2000; Dogan and Boor, 2003; Gunasekera et al., 2003), which are unwanted because they have been associated with spoilage of milk (Sørhaug and Stepaniak, 1997). Staphylococci are part of the ubiquitous aerobic mesophilic microorganisms of raw milk (Özer, 2000), but CPS may represent a human hazard. Coliforms remained almost unchanged during the process while thermoduric enterococci showed a slight increase in number. Coliforms are undesired since they may include pathogenic species. Butyric clostridia were never detected showing that the final products do not have the risk of late blowing caused by Clostridium spp.

An opposite trend was shown by LAB, which increased in cell concentration till $10^{8}-10^{9} \mathrm{CFU} \mathrm{g}{ }^{-1}$ for the thermophilic group of cocci in acidified curd samples. Raw cows' milk is generally contaminated by LAB; values of $10^{2}-10^{3} \mathrm{CFU} \mathrm{mL} \mathrm{m}^{-1}$ have been reported for milk after milking (Delbès et al., 2007; Desmasures et al., 1997), but higher levels, up to $10^{5}-10^{6} \mathrm{CFU} \mathrm{mL}{ }^{-1}$ may be easily reached when milk is left at room temperature for a while before processing (Franciosi et al., 2009).

A total of 1272 presumptive LAB were isolated from the different samples and vat surface. They were phenotypically divided into seven groups which included 34 different strains. Fifteen species belonging to six LAB genera (Enterococcus, Lactobacillus, Lactococcus, Leuconostoc, Streptococcus and Weissella) were identified. Except for Weissella, all other LAB genera are commonly associated with raw milk (Wouters et al., 2002; Franciosi et al., 2009; Franciosi et al., 2011), fermented milk matrices and Caciocavallo type cheese (Piraino et al., 2005; Morea et al., 2007; Piraino et al., 2008).

The species most frequently isolated from the majority of samples (except milk at delivery) was $S$. thermophilus. This species has been found to dominate during manufacturing of other similar Italian pasta-filata cheeses, such as Provolone del Monaco and Scamorza Altamurana (Baruzzi et al., 2002; Aponte et al., 2008) which do not contain commercial starters. The species $S$. thermophilus is part of the LAB employed as thermophilic starter cultures and it is generally present in the NWSC used for cooked cheese and "pasta filata" cheese production (Parente et al., 1998; Settanni and Moschetti, 2010). S. thermophilus was found in the wooden vat of our investigation at high cell levels and, since similar results were found for the vats used for Ragusano PDO cheese manufacturing (Licitra et al., 2007; Lortal et al., 2009), it may be concluded that the wooden vat analyzed in this work acted as a source of $S$. thermophilus for the inoculation of milk.

The acidification of curd is essential for the operation of stretching, thus, the presence of acidifying S. thermophilus strains is of paramount importance for Caciocavallo Palermitano cheese production. Traditional and standard cheese manufactures were characterized by similar TTA values of curd before and after acidification. These data demonstrated that the indigenous $S$. thermophilus strains of wooden vat origin played, for traditional cheese making, the same role played by the commercial starter culture preparation for standard productions.

Among the other species identified in this work, Lc. lactis and $L n$. mesenteroides are the main components of mesophilic milk starter cultures for dairy fermentations, while $L b$. alimentarius and $L$ b. parabuchneri are responsible for the ripening of cheeses (Settanni and Moschetti, 2010). Lc. garvieae and S. macedonicus are associated with raw milk (Franciosi et al., 2009), but also employed as secondary adjunct cultures (Fortina et al., 2007; Settanni et al., 2011). Streptococcus bovis is a pathogen bacterium (Vaska and Faoagali, 2009) which was revealed in the bulk milk, but not detected elsewhere.

A very low percentage of lactobacilli was revealed by genetic identification, despite the high counts detected on the media (MRS and 
WBAM) used for mesophilic and thermophilic rod LAB. These results confirmed our practical observations that LAB cocci are able to develop colonies on the above media, even though at lower levels than those estimated on the medium (M17) generally used for mesophilic and thermophilic cocci $\mathrm{LAB}$, probably due to the lower $\mathrm{pH}$ of MRS and WBAM.

Six species of Enterococcus genus (E. casseliflavus, E. durans, E. faecalis, E. faecium, E. gallinarum and E. italicus) were identified in the present study. Several strains of this group of raw milk origin are linked to the typicality of the final cheeses (Foulquié Moreno et al., 2006). The species E. faecalis, after $S$. thermophilus, was frequently detected in the samples analyzed. It was also found in the stretched curd, although at lower numbers than S. thermophilus. Thus, E. faecalis cannot have had a defining acidifying role, but its role during ripening deserves to be investigated.

The results of this work demonstrate a high biodiversity in terms of LAB species and the species found to dominate the curd after cooking, acidification and stretching was S. thermophilus. Six strains were found in the wooden vat and four of them were associated to each step of manufacturing. By contrast, the standard productions showed a low streptococcal diversity, represented by the S. thermophilus strain added with the freeze-dried starter culture preparation.

Our results showed that the $S$. thermophilus strains found in the wooden vat analyzed all contributed to the acidification of curd, thus, they formed a stable consortium. The same strains were found in the wooden vat analyzed through 21 days of production, independently on the bulk milk daily processed. The standard productions were carried out in a stainless steel vat, whose internal surfaces did not host LAB, and for this reason needed the inoculation of a starter culture preparation for the acidification of curd. Hence, compared to the standard cheese manufactures, traditional productions do not rely on exogenous starter culture inoculums, since the indigenous wooden vat $S$. thermophilus strains are active. Those strains are highly adapted to the dairy factory environment, as well as to the technological conditions applied for cheese making, and, for these reasons, may be considered autochthonous for this production of Caciocavallo Palermitano cheese. Moreover, the stretched curd of traditional production is characterized by a higher $S$. thermophilus biodiversity than standard production. This may influence the features of the final cheeses, since LAB biodiverdity is considered a key factor for the organoleptic features of artisanal cheeses (Franciosi et al., 2009).

\section{Conclusions}

With regards to the objectives of this study, four main conclusions can be draft: 1) the traditional Caciocavallo Palermitano cheese productions analyzed were safe, since the wooden equipment did not contaminate milk with pathogenic species, such as Salmonella spp., L. monocytogenes and CPS; 2) several LAB were found during the whole transformation process of milk into cheese, with $S$. thermophilus being the dominant species; 3 ) the wooden vat examined acted as a reservoir of LAB for the inoculation of milk; 4) some $S$. thermophilus strains persisted during the production line and may be considered autochthonous for this Caciocavallo Palermitano cheese production.

\section{Acknowledgments}

This research was financially supported by Regione Siciliana, Assessorato Agricoltura e Foreste, project "PROLACTIS". We wish to thank the staff of Caseificio di Godrano (Godrano, Palermo, Italy) for its supervision during cheese production. The authors are also grateful to the students Angelo Gambino and Maria Pia Leone (University of Palermo) for their help with microbiological analysis.

\section{References}

Alegría, Á., Álvarez-Martín, P., Sacristán, N., Fernández, E., Delgado, S., Mayo, B., 2009. Diversity and evolution of the microbial populations during manufacture and ripening of Casín, a traditional Spanish, starter-free cheese made from cow's milk. International Journal of Food Microbiology 136, 44-51.

Altschul, S.F., Madden, T.L., Schäffer, A.A., Zhang, J., Zhang, Z., Miller, W., 1997. Grapped BLAST and PSI-BLAST: a new generation of protein database search programs. Nucleic Acids Research 25, 3389-3402.

AOAC, 2005. Official Method 920.124. Chapter 33 Association of Official Analytical Chemists, USA.

Aponte, M., Fusco, V., Andolfi, R., Coppola, S., 2008. Lactic acid bacteria occurring during manufacture and ripening of Provolone del Monaco cheese: detection by different analytical approaches. International Dairy Journal 18, 403-413.

Baruzzi, F., Maturante, A., Morea, M., Cocconcelli, P.S., 2002. Microbial community dynamics during the Scamorza Altamurana cheese natural fermentation. Journal of Dairy Science 85, 1390-1397.

Bonanno, A., Di Grigoli, A., Tornambè, G., Formoso, B., Alicata, M.L., Procida, G., Manzi, P., Marconi, S., Pizzoferrato, L., 2004. Effects of feeding regime on nutritional and aromatic characteristics of Caciocavallo Palermitano cheese. Proc. of the 6th International Meeting on Mountain Cheeses: "Dairy food biodiversity: flavour and health properties", pp. 43-50. CORFILAC editions, Ragusa, Italy.

Corsetti, A., Lavermicocca, P., Morea, M., Baruzzi, F., Tosti, N., Gobbetti, M., 2001. Phenotypic and molecular identification and clustering of lactic acid bacteria and yeasts from wheat (species Triticum durum and Triticum aestivum) sourdoughs of Southern Italy. International Journal of Food Microbiology 64, 95-104.

Delbès, C., Ali-Mandjee, L., Montel, M.-C., 2007. Monitoring bacterial communities in raw milk and cheese by culture dependent and independent 16S rRNA gene based analyses. Applied and Environmental Microbiology 73, 1882-1891.

Desmasures, N., Bazin, F., Guéguen, M., 1997. Microbiological composition of raw milk from selected farms in the Camambert region of Normandy. Journal of Applied Microbiology 83, 53-58.

Dogan, B., Boor, K.J., 2003. Genetic diversity and spoilage potentials among Pseudomonas spp. isolated from fluid milk products and dairy processing plants. Applied and Environmental Microbiology 69, 130-138.

Fortina, M.G., Ricci, G., Foschino, R., Picozzi, C., Dolci, P., Zeppa, G., Cocolin, L., Manichini, P.L. 2007. Phenotypic typing, technological properties and safety aspects of Lactococcus garvieae strains from dairy environments. International Dairy Journal 103, 445-453.

Foulquié Moreno, M.R., Sarantinopoulos, P., Tsakalidou, E., De Vuyst, L., 2006. The role and application of enterococci in food and health. International Journal of Food Microbiology 106, 1-24.

Franciosi, E., Settanni, L., Cavazza, A., Poznanski, E., 2009. Biodiversity and technological potential of wild lactic acid bacteria from raw cows' milk. International Dairy Journal $19,3-11$.

Franciosi, E., Settanni, L., Cologna, N., Cavazza, A., Poznanski, E., 2011. Microbial analysis of raw cows' milk used for cheese-making: influence of storage treatments on microbial composition and other technological traits. World Journal of Microbiology and Biotechnology 27, 171-180.

Gregersen, T., 1978. Rapid method for distinction of Gram-negative from Grampositive bacteria. Applied Microbiology and Biotechnology 5, 123-127.

Gunasekera, T.S., Dorsch, M.R., Slade, M.B., Veal, D.A., 2003. Specific detection of Pseudomonas spp. in milk by fluorescence in situ hybridization using rRNA directed probes. Journal of Applied Microbiology 94, 936-945.

Heeschen, W.H., 1996. Bacteriological quality of raw milk: legal requirements and payment systems. Proceedings IDF Symposium Bacteriological quality of raw milk. Wolfpassing, Austria. IDF, Brussels, Belgium, pp. 1-18.

Holzapfel, W.H., Geisen, R., Schillinger, U., 1995. Biological preservation of foods with reference to protective cultures, bacteriocins and food-grade enzymes. International Journal of Food Microbiology 24, 343-362.

Licitra, G., Ogier, J.C., Parayre, S., Pediliggieri, C., Carnemolla, T.M., Falentin, H., Madec, M.N., Carpino, S. Lortal, S., 2007. Variability of bacterial biofilms of the "Tina" wood vats used in the Ragusano cheese-making process. Applied and Environmental Microbiology 73, 6980-6987.

Lortal, S., Di Blasi, A., Madec, M.-N., Pediliggieri, C., Tuminello, L., Tanguy, G., Fauquant, J. Lecuona, Y., Campo, P., Carpino, S., Licitra, G., 2009. Tina wooden vat biofilm. A safe and highly efficient lactic acid bacteria delivering system in PDO Ragusano cheese making. International Journal of Food Microbiology 132, 1-8.

Mariani, C., Briandet, R., Chamba, J.F., Notz, E., Carnet-Pantiez, A., Eyoug, R.N., Oulahal, N., 2007. Biofilm ecology of wooden shelves used in ripening the French raw milk smear cheese reblochon de Savoie. Journal of Dairy Science 90, 1653-1661.

Morea, M., Matarante, A., Di Cagno, R., Baruzzi, F., Minervini, F., 2007. Contribution of autochthonous non-starter lactobacilli to proteolysis in Caciocavallo Pugliese cheese. International Dairy Journal 17, 525-534.

Mucchetti, G., Bonvini, B., Remagni, M.C., Ghiglietti, R., Locci, F., Barzaghi, S., Francolino, S, Perrone, A, Rubiloni, A, Campo, P, Gatti, M. Carminati, D, 2008, Influence of cheese-making technology on composition and microbiological characteristics of Vastedda cheese. Food Control 19, 119-125.

Murphy, S.C., Boor, K.J., 2000. Trouble-shooting sources and causes of high bacteria counts in raw milk. Dairy Food and Environmental Sanitation 20, 606-611.

Nieto-Arribas, P., Seseña, S., Poveda, J.M., Palop, L., Cabezas, L., 2009. Genotypic and technological characterization of Lactococcus lactis isolates involved in processing of artisanal Manchego cheese. Journal of Applied Microbiology 107, 1505-1517.

Özer, B.H., 2000. Microbiology of liquid milk. In: Robinson, R.K., Batt, C.A., Patel, P.D. (Eds.), Encyclopedia of Food Microbiology. Academic Press, London, pp. 1436-1441.

Parente, E., Moschetti, G., Coppola, S., 1998. Starter cultures for Mozzarella cheese. Annali di Microbiologia ed Enzimologia 48, 89-109. 
Petrova, N., 1975. Microbiological process in Vitosha Kachkaval. Khranitelna Promishlenost 24, 33-35.

Piraino, P., Zotta, T., Ricciardi, A., Parente, E., 2005. Discrimination of commercial Caciocavallo cheeses on the basis of the diversity of lactic microflora and primary proteolysis. International Dairy Journal 15, 1138-1149.

Piraino, P., Zotta, T., Ricciardi, A., McSweeney, P.L.H., Parente, E., 2008. Acid production, proteolysis, autolytic and inhibitory properties of lactic acid bacteria isolated from pasta filata cheeses: a multivariate screening study. International Dairy Journal 18, $81-92$.

Psoni, L, Kotzamanidis, C., Yiangou, M., Tzanetakis, N., Litopoulou-Tzanetaki, E., 2007. Genotypic and phenotypic diversity of Lactococcus lactis isolates from Batzos, a Greek PDO raw goat milk cheese. International Journal of Food Microbiology 114, 211-220.

Salvadori del Prato, O., 1998. Le paste filate. In: Salvadori del Prato, O. (Ed.), Tecnologia Lattiero-Casearia. Edagricole, Bologna, pp. 588-641.

Settanni, L., Moschetti, G., 2010. Non-starter lactic acid bacteria used to improve cheese quality and provide health benefits. Food Microbiology 27, 691-697.

Settanni, L., Franciosi, E., Cavazza, A., Cocconcelli, P.S., Poznanski, E., 2011. Extension of Tosèla cheese shelf-life using non-starter lactic acid bacteria. Food Microbiology 28, 883-890.

Slaghuis, B., 1996. Sources and significance of contaminants on different levels of raw milk production. Proceedings IDF Symposium Bacteriological quality of raw milk. Wolfpassing, Austria. IDF, Brussels, Belgium, pp. 19-27.

Sørhaug, T., Stepaniak, L., 1997. Psychrotrophs and their enzymes in milk and dairy products: quality aspects. Trends in Food Science and Technology 8, 35-40.

Stackebrandt, E., Goebel, B.M., 1994. Taxonomic note. A place for DNA-DNA reassociation and 16S rRNA sequence analysis in the present species definition in bacteriology. International Journal of Systematic Bacteriology 44, 846-849.
Stenlid, J., Karlsson, J.O., Hogberg, N., 1994. Intra-specific genetic variation in Heterobasidium annosum revealed by amplification of minisatellite DNA. Mycological Research 98, 57-63.

Topisirovic, L., Kojic, M., Fira, D., Golic, N., Strahinic, I., Lozo, J., 2006. Potential of lactic acid bacteria isolated from specific natural niches in food production and preservation. International Journal of Food Microbiology 112, 230-235.

Tornambè, G., Di Grigoli, A., Alicata, M.L., De Pasquale, C., Bonanno, A., 2009. Comparing quality characteristics of "Caciocavallo Palermitano" cheese from traditional and intensive production systems. Proc. 15th Meeting of the FAO-CIHEAM Mountain Pastures Network, Les Diablerets, Switzerland, pp. 153-156.

van den Braak, N., Power, E., Anthony, R., Endtz, H., Verbrugh, H.A., Van Belkum, A. 2000. Random amplification of polymorphic DNA versus pulsed field gel electrophoresis of Smal DNA macrorestriction fragments for typing strains of vancomycin-resistant enterococci. FEMS Microbiology Letters 192, 45-52.

Vaska, V. L Faoagali, J.L 2009. Streptococcus bovis bacteraemia: identification within organism complex and association with endocarditis and colonic malignancy. Pathology 41, 183-186

Weisburg, W., Barns, S.M., Pelletier, D.A., Lane, D.J., 1991. 16S ribosomal DNA amplification for phylogenetic study. Journal of Bacteriology 173, 697-703.

Wiedmann, M., Weilmeier, D., Dineen, S.S., Ralyea, R., Boor, K.J., 2000. Molecular and phenotypic characterization of Pseudomonas spp. isolated from milk. Applied and Environmental Microbiology 66, 2085-2095.

Wouters, J.T.M., Ayad, E.H., Hugenholtz, J., Smit, G., 2002. Microbes from raw milk for fermented dairy products. International Dairy Journal 12, 91-109.

Zapparoli, G., Torriani, S., Dellaglio, F., 1998. Differentiation of Lactobacillus sanfranciscensis strains by randomly amplified polymorphic DNA and pulsed-field gel electrophoresis. FEMS Microbiology Letters 166, 324-332. 